\title{
Effects of streptokinase in patients presenting within 6 hours of prolonged chest pain with ST segment depression
}

Harvey D White, John K French, Robin M Norris, Barbara F Williams, Hamish H Hart, David B Cross dictive value for myocardial infarction at presentation $(P=0 \cdot 008$, stepwise logistic regression). ST depression $\geqslant 2 \mathrm{~mm}$ was predictive of death, late development of myocardial infarction, or a need for angiography $(P=0 \cdot 02)$.

Conclusion-Patients presenting with ischaemic chest pain and ST depression frequently develop myocardial infarction. Severe ST depression is predictive of an adverse outcome. The 35 day (3.6\% cardiac and total) and 1 year mortality (8.9\% total, 6.3\% cardiac) are low with conservative management and expeditious revascularisation. Streptokinase treatment within $6 \mathrm{~h}$ of the last episode of pain does not seem to be beneficial.

(Br Heart f 1995;73:500-505)

Keywords: unstable angina; thrombolytic treatment; ST depression

Angiography and angioscopy have identified intracoronary thrombus in many patients presenting with recent chest pain and ST depression. ${ }^{1-4}$ Traditional treatment has used antianginal medication such as $\beta$ blockers, nitrates, and calcium channel blockers, but these agents do not have a significant effect on intracoronary thrombus and have not been shown to reduce the incidence of myocardial infarction or death. Antiplatelet and antithrombin treatments that are particularly directed at thrombus, however, have been shown to be beneficial in patients with unstable angina. ${ }^{5-8}$

Thrombolytic treatment decreases the amount of intracoronary thrombus, ${ }^{29}$ but the effects of such treatment on clinical end points have been variable, with some studies suggesting benefit while others have not. ${ }^{10-17}$ The second international study of infarct survival (ISIS-2) and gruppo italiano per lo studio della streptochinasi nell'infarto miocardico (GISSI-1) studies showed that thrombolytic treatment with streptokinase in patients with ST depression was associated with no evidence of benefit and a 1 month mortality of $19-20 \% .^{18} 19$ The results reflect in part the clinical heterogeneity of the patients included in the studies.

We hypothesised that if thrombolytic treatment could lyse intracoronary thrombus and allow healing and stabilisation of the disrupted plaque, subsequent management
Correspondence to: Dr H D White, Green Lane Hospital, Epsom, Auckland 1003, New Zealand. Accepted for publication 20 December 1994 procedures. Three patients (two streptokinase and one placebo) required transfusion. ST depression $\geqslant 3 \mathrm{~mm}$ had $90 \%$ specificity but only $60 \%$ positive pre- 
could be based on the amount of inducible ischaemia and not mandated by the presenting clinical features and coronary arteriographic findings. We therefore examined the effect of streptokinase in patients whom we considered to have a high likelihood of intracoronary thrombus and a high risk of developing myocardial infarction. Patients presenting within $6 \mathrm{~h}$ of an episode of chest pain at rest of at least $20 \mathrm{~min}$ duration and with $\geqslant 1 \mathrm{~mm}$ ST depression were randomised to receive either streptokinase $(1.5$ million units over 30 minutes) or placebo in a double blind manner.

\section{Patients and methods}

\section{PATIENT POPULATION}

Consecutive patients aged $\leqslant 75$ years presenting to three coronary care units in Auckland within $6 \mathrm{~h}$ of an episode of chest pain at rest of at least $20 \mathrm{~min}$ duration and with $\geqslant 1 \mathrm{~mm}$ ST depression (0.04 $\mathrm{mm}$ after the $\mathrm{J}$ point) in any electrocardiogram lead were entered in the trial from 1 November 1989 to 31 January 1992. The exclusion criteria were recent trauma including prolonged cardiac massage, a history of stroke, gastric or genitourinary bleeding during the previous 2 months, concurrent life threatening disease, sustained systolic blood pressure $>200 \mathrm{~mm} \mathrm{Hg}$, and previous streptokinase treatment. Patients without contraindications received antiplatelet agents. Concurrent medication was given according to the physician's practice. It was recommended, however, that $\beta$ blockers, oral nitrates, calcium channel blockers, intravenous glyceryl trinitrate, and heparin be used in that order and incrementally according to symptoms.

\section{END POINTS}

The primary end point within 35 days of initial presentation was a composite of death, development of myocardial infarction, need for angiography because of continuing ischaemic pain uncontrolled by medication, or a positive exercise test defined as $>1 \mathrm{~mm}$ ST depression within 6 min of the Bruce protocol associated with dyspnoea or chest pain. Secondary end points were safety, readmis-

Table 1 Baseline characteristics

\begin{tabular}{|c|c|c|}
\hline & $\begin{array}{l}\text { Streptokinase } \\
(n=57)\end{array}$ & $\begin{array}{l}\text { Placebo } \\
(n=55)\end{array}$ \\
\hline $\begin{array}{l}\text { Age (years) } \\
\text { Male } \\
\text { Previous angina } \\
\text { Previous myocardial infarction } \\
\text { Previous CABG } \\
\text { Hypertension } \\
\text { Diabetes mellitus } \\
\text { Current smoking } \\
\text { Cholesterol }(\mathrm{mmol} / \mathrm{l}) \\
\text { Triglycerides }(\mathrm{mmol} / \mathrm{l}) \\
\text { HDL cholesterol }(\mathrm{mmol} / \mathrm{l}) \\
\text { LDL cholesterol }(\mathrm{mmol} / \mathrm{l})\end{array}$ & $\begin{array}{l}63(11) \\
38(67) \\
36(63) \\
20(35) \\
6(11) \\
27(47) \\
9(16) \\
12(21) \\
6 \cdot 5(1 \cdot 4) \\
2 \cdot 2(1 \cdot 5) \\
1 \cdot 1(0 \cdot 4) \\
4 \cdot 6(1 \cdot 3)\end{array}$ & $\begin{array}{l}63(9) \\
42(76) \\
33(60) \\
18(33) \\
9(16) \\
17(31) \\
2(4) \\
17(31) \\
6 \cdot 4(1 \cdot 3) \\
1 \cdot 7(1 \cdot 6) \\
1 \cdot 0(0 \cdot 7) \\
4.4(1 \cdot 1)\end{array}$ \\
\hline
\end{tabular}

Values in parentheses are percentages except for age and lipid concentrations (mean (SD)). *There were no differences in baseline characteristics between the groups except for diabetes $(\mathrm{P}=0.04)$. CABG, coronary artery bypass grafting; HDL, high density lipoprotein; LDL, low density lipoprotein sion with myocardial infarction or unstable angina, need for revascularisation after 35 days, and the number of episodes of chest pain recorded by patient diaries during the first 35 days. A conservative policy was adopted towards cardiac catheterisation, the indication being recurrent angina uncontrolled by medication or associated with electrocardiographic changes at rest or during exercise testing before $6 \mathrm{~min}$ of the Bruce protocol. Revascularisation was performed for left main coronary artery stenosis or for symptoms unable to be controlled by medical treatment. Patients were followed for 1 year.

Myocardial infarction was defined as chest pain associated with a peak creatine kinase of twice normal for our laboratory $(>600 \mathrm{U} / \mathrm{ml})$ in conjunction with the development of $Q$ waves, or evolutionary ST or T wave changes. Serum creatine kinase was measured on admission and at 12, 24, 48, and $72 \mathrm{~h}$. Patients with creatine kinase greater than twice normal within $12 \mathrm{~h}$ were considered to have myocardial infarction on presentation. The severity of ST depression was examined as a predictor of myocardial infarction at presentation and for a composite outcome of death, late myocardial infarction $(>12 \mathrm{~h}$ after admission), or need for urgent angiography.

\section{STATISTICAL ANALYSIS}

To show a reduction (power $80 \%$; $\mathrm{P}<0.05$ ) from $80 \%$ to $55 \%$ in the end points of death, myocardial infarction, need for angiography or a positive exercise test, 54 patients in each group would be required. Results for continuous variables are expressed as mean (SD) and differences between means are compared by one way analysis of variance. All $p$ values are two tailed. Categoric variables are compared by the $\chi^{2}$ test with Yates' correction for continuity in $2 \times 2$ tables; $P<0.05$ was regarded as significant. Stepwise logistic regression was performed entering all baseline variables into the model.

\section{Results}

112 consecutive patients presenting within $6 \mathrm{~h}$ of ischaemic chest pain at rest and with $\geqslant 1$ mm ST depression on the presentation electrocardiogram were randomised in a double blind manner to receive either streptokinase 1.5 million $u(n=57)$ or placebo $(n=55)$. One year follow up was completed in $99.1 \%$, with one patient moving overseas. The baseline characteristics of the patient groups were similar (table 1). Antiplatelet treatment was administered to $97 \%$ of patients: 70 received aspirin and 39 the thromboxane $A_{2}$ receptor antagonist GR32191. Of the three patients who did not receive antiplatelet agents, two were taking non-steroidal anti-inflammatory drugs and one had thrombocytopenia. Other concurrent medication during the first $48 \mathrm{~h}$ was according to the preference of the physician (table 2).

\section{EFFECTS OF STREPTOKINASE}

The frequency of the combined hierarchical 
end point of death, myocardial infarction, early angiography, or a positive exercise test was $82 \%$ ( 47 of 57 patients) with streptokinase and $75 \%$ (41 of 55 patients) with placebo (table 3 ). Two patients in each group died in hospital (two of shock in the streptokinase group, one of shock and one of rupture in the placebo group). Twenty seven patients $(47 \%)$ in the streptokinase group and 22 $(40 \%)$ in the placebo suffered a myocardial infarction. An initial increase in creatine kinase $>600 \mathrm{U} / \mathrm{ml}$ occurred more than $12 \mathrm{~h}$

Table 2 Concurrent treatment (0-48 hours)

\begin{tabular}{lll}
\hline & $\begin{array}{l}\text { Streptokinase } \\
(n=57)\end{array}$ & $\begin{array}{l}\text { Placebo } \\
(n=55)\end{array}$ \\
\hline Aspirin & $36(63)$ & $34(62)$ \\
Other antiplatelet agent & $20(35)$ & $19(35)$ \\
No antiplatelet agent & $1(2)$ & $2(4)$ \\
$\beta$ blocker & $22(39)$ & $28(51)$ \\
Oral nitrates & $18(32)$ & $19(35)$ \\
Intravenous nitrates & $2(4)$ & $9(16)$ \\
Calcium antagonists & $17(30)$ & $21(38)$ \\
Heparin (intravenous) & $7(12)$ & $10(18)$ \\
\hline
\end{tabular}

Values in parenthesis are percentages.

Table 3 Patient outcomes at 35 days

\begin{tabular}{lcc}
\hline & $\begin{array}{c}\text { Streptokinase } \\
(n=57)\end{array}$ & $\begin{array}{l}\text { Placebo } \\
(n=55)\end{array}$ \\
\hline Primary end points & 2 & 2 \\
Death & $27(24)$ & $22(21)$ \\
Myocardial infarction & $8(3)$ & $3(1)$ \\
Early angiogram & $22(14)$ & $22(14)$ \\
Positive exercise test & 10 & 14 \\
Freedom from the above & 10 & $508[41]$ \\
Secondary end points & $604[42]$ & $190[41]$ \\
Episodes of chest pain & $206(36)$ & 5 \\
Chest pain in hospital & 5 & 8 \\
Readmission & 10 & 2 \\
CABG & 0 & \\
Angioplasty & &
\end{tabular}

Values in parentheses are the ranking of end points in the hierachial order death, myocardial infarction, early angiogram achial order death, myocardial infarction, early angiogram, $4 \times 2=0.80, p>0.5)$. Values in square brackets are the $4 \times 2=0.80, p>0.5)$. Values in square brackets are the number of patients with recurrent pain. ${ }^{\star}$ Defined as $\geqslant 1 \mathrm{~mm}$ ST depression associated with either chest pain or breathlessness within $6 \mathrm{~min}$ of the Bruce protocol. CABG, coronary artery bypass grafting.

Table 4 Severity of ST depression and development of myocardial infarction

\begin{tabular}{lllll}
\hline & \multicolumn{2}{c}{ At presentation } & \multicolumn{2}{c}{ During admission } \\
\cline { 2 - 5 } & $\geqslant 2$ & $\geqslant 3$ & $\geqslant 2$ & $\geqslant 3$ \\
\hline Sensitivity (\%) & 50 & 35 & 40 & 29 \\
$\begin{array}{l}\text { Specificity (\%) } \\
\begin{array}{l}\text { Positive predictive } \\
\text { value (\%) }\end{array}\end{array}$ & 63 & 90 & 63 & 90 \\
\hline
\end{tabular}

Table 5 Multivariate analysis of risk of a composite of adverse outcomes *

\begin{tabular}{|c|c|c|c|c|c|c|}
\hline Variable & $\begin{array}{l}\text { Parameter } \\
\text { estimate }\end{array}$ & $\begin{array}{l}\text { Standard } \\
\text { error }\end{array}$ & $\chi^{2}$ & $\begin{array}{l}\text { Probability } \\
>\chi^{2}\end{array}$ & $\begin{array}{l}\text { Standardised } \\
\text { estimate }\end{array}$ & $\begin{array}{l}\text { Odds } \\
\text { ratio }\end{array}$ \\
\hline $\begin{array}{l}\text { Intercept } \\
\text { Age } \geqslant 70 \text { years } \\
\text { Male } \\
\text { Previous infarction } \\
\text { Hypertension } \\
\text { Diabetes } \\
\text { Previous CABG } \\
\text { ST depression } \\
\geqslant 2 \text { mm } \dagger\end{array}$ & $\begin{array}{r}1 \cdot 1748 \\
-0.0606 \\
0.4035 \\
-0.5119 \\
0.5737 \\
0.5636 \\
-0.4482 \\
-1.1472\end{array}$ & $\begin{array}{l}0.7221 \\
0.5168 \\
0.5329 \\
0.5096 \\
0.5300 \\
0.8153 \\
0.6636 \\
0.4917\end{array}$ & $\begin{array}{l}2 \cdot 6470 \\
0 \cdot 0137 \\
0.5734 \\
1 \cdot 0094 \\
1 \cdot 1717 \\
0 \cdot 4779 \\
0 \cdot 4561 \\
5 \cdot 4434\end{array}$ & $\begin{array}{l}0.1037 \\
0.9067 \\
0.4489 \\
0.3150 \\
0 \cdot 2790 \\
0 \cdot 4894 \\
0.4994 \\
0.0196\end{array}$ & $\begin{array}{r}-0.015986 \\
0.100948 \\
-0.134238 \\
0.155172 \\
0.092895 \\
-0.084532 \\
-0.312556\end{array}$ & $\begin{array}{l}3 \cdot 238 \\
0.941 \\
1.497 \\
0.599 \\
1.775 \\
1.757 \\
0.639 \\
0.318\end{array}$ \\
\hline $\begin{array}{l}\text { Smoking } \\
\text { Cholesterol }\end{array}$ & $\begin{array}{l}0.7517 \\
0.2790\end{array}$ & $\begin{array}{l}0.6570 \\
0.5183\end{array}$ & $\begin{array}{l}1 \cdot 3091 \\
0 \cdot 2897\end{array}$ & $\begin{array}{l}0 \cdot 2526 \\
0 \cdot 5904\end{array}$ & $\begin{array}{l}0 \cdot 182362 \\
0 \cdot 074806\end{array}$ & $\begin{array}{l}2 \cdot 121 \\
1.322\end{array}$ \\
\hline
\end{tabular}

Death, development of late myocardial infarction, or the need for urgent angiography. $+\mathrm{P}<0.01$, stepwise logistic regression. CABG, coronary artery bypass grafting. after admission in 16 patients (eight streptokinase and eight placebo). Fourteen patients (six streptokinase and eight placebo) had a $Q$ wave and 35 (21 streptokinase, 14 placebo) a non- $Q$ wave myocardial infarction.

Eleven patients required cardiac catheterisation because of angina uncontrolled by medical treatment, nine of whom had $\geqslant 2$ $\mathrm{mm}$ ST depression associated with chest pain. Of the remaining 101 patients, 90 underwent exercise testing within 5 weeks of presentation. Of the 11 patients who did not undergo exercise testing, four had died, five were precluded by other serious medical conditions, and in two cases the physician declined. Forty four patients had $\geqslant 1 \mathrm{~mm}$ ST depression within $6 \mathrm{~min}$ of exercise associated with chest pain or dyspnoea (22 each in the streptokinase and placebo groups); 10 stopped within $6 \mathrm{~min}$ because of fatigue, leg pain, or either angina or dyspnoea without ST changes.

There was no difference in the secondary end point of recorded episodes of chest pain. Eighty three patients (42 streptokinase, 41 placebo) had recurrent chest pain over 35 days with 604 episodes in the streptokinase group and 508 in the placebo (table 3). Nor was there any difference in the number of episodes of chest pain in hospital (206 streptokinase $v 190$ placebo). There were no differences in the recorded episodes of chest pain in the first $24 \mathrm{~h}$ (11 streptokinase $v 15$ placebo) or $48 \mathrm{~h}$ (27 streptokinase $v 38$ placebo).

Revascularisation was performed in 10 patients in the streptokinase group and 10 in the placebo for severe symptoms or left main stenosis (two streptokinase, one placebo). There was no haemorrhagic stroke. Three patients (two streptokinase, one placebo) had ischaemic stroke. Three patients (two streptokinase, one placebo) required transfusion for bleeding.

\section{ST SEGMENT DEPRESSION AND OUTCOME}

While ST depression $\geqslant 3 \mathrm{~mm}$ was $90 \%$ specific for myocardial infarction at either presentation or any stage during admission (table 4), the sensitivity was low (35\% and $29 \%$ respectively). ST depression of $\geqslant 3 \mathrm{~mm}$ was the only baseline characteristic predictive of myocardial infarction at presentation $(\mathbf{P}=$ 0.008 , stepwise logistic regression). On multivariate analysis of all baseline characteristics (table 5) ST depression $\geqslant 2 \mathrm{~mm}$ was the only predictor of a composite end point of death, development of myocardial infarction, or the need for urgent angiography $(P=0.02)$, but it was not predictive of a combined end point which also included the presence of a positive exercise test $(P=0 \cdot 2)$. The effect of streptokinase on outcome was similar to that of placebo regardless of the degree of ST depression on admission (table 6).

OUTCOME AT 1 YEAR

During the year after initial presentation there were no significant differences in outcome between the streptokinase and placebo groups (table 7). There were three further cardiac and three non-cardiac deaths. Two patients 
Table 6 Outcome according to amount of ST depression and treatment

\begin{tabular}{|c|c|c|c|c|}
\hline & \multicolumn{2}{|l|}{$<2 \mathrm{~mm}$} & \multicolumn{2}{|l|}{$\geqslant 2 \mathrm{~mm}$} \\
\hline & $\begin{array}{l}\text { Streptokinase } \\
(n=31)\end{array}$ & $\begin{array}{l}\text { Placebo } \\
(n=35)\end{array}$ & $\begin{array}{l}\text { Streptokinase } \\
(n=26)\end{array}$ & $\begin{array}{l}\text { Placebo } \\
(n=20)\end{array}$ \\
\hline $\begin{array}{l}\text { Death } \\
\text { Myocardial infarction } \\
\text { Urgent angiography } \\
\text { Positive exercise test } \\
\text { Freedom from the above } \\
\text { Episodes of chest pain } \\
\text { Readmission } \\
\text { CABG } \\
\text { Angioplasty }\end{array}$ & $\begin{array}{l}0 \\
14 \\
1 \\
12 \\
7 \\
332[21] \\
3 \\
4 \\
0\end{array}$ & $\begin{array}{l}0 \\
12 \\
1 \\
14 \\
11 \\
280[24] \\
3 \\
2 \\
2\end{array}$ & $\begin{array}{r}2 \\
13 \\
7 \\
10 \\
3 \\
272[21] \\
0 \\
6 \\
0\end{array}$ & $\begin{array}{c}2 \\
10 \\
2 \\
8 \\
3 \\
228[17] \\
4 \\
6 \\
0\end{array}$ \\
\hline
\end{tabular}

Values in square brackets are the number of patients with recurrent pain. CABG, coronary artery bypass grafting.

Table 7 Total events from day 0 to 1 year

\begin{tabular}{lcc}
\hline & $\begin{array}{c}\text { Streptokinase } \\
(n=57)\end{array}$ & $\begin{array}{l}\text { Placebo } \\
(n=55)\end{array}$ \\
\hline Death & $5(9)$ & $5(9)$ \\
Non-fatal MI & $27(47)$ & $22(40)$ \\
Reinfaction & $2(4)$ & $1(2)$ \\
CABG & $11(19)$ & $14(25)$ \\
Angioplasty & $2(4)$ & $2(4)$ \\
Freedom from the above & $17(30)$ & $19(35)$ \\
\hline
\end{tabular}

Values in parentheses are percentages. CABG, coronary artery bypass grafting.

receiving placebo died of heart failure and one patient receiving streptokinase died suddenly. Two non-cardiac deaths were caused by chronic renal failure (both streptokinase) and one by chronic obstructive pulmonary disease (placebo). There were 17 readmissions for unstable angina (10 streptokinase and seven placebo) and revascularisation was required in nine patients (three streptokinase and six placebo). The total mortality at 1 year was $8.9 \%$ (cardiac $6.3 \%$ ).

\section{Discussion}

This study shows that thrombolytic treatment with streptokinase has no effect on a combined end point of death, myocardial infarction, need for angiography for ischaemia not controlled by medical therapy, or inducible ischaemia within $6 \mathrm{~min}$ of exercise on the Bruce protocol. Patients presenting within $6 \mathrm{~h}$ of chest pain of at least 20 min duration associated with continuing ST depression were enrolled. We considered that this group of patients would be most likely to have intracoronary thrombus.

Thrombolytic treatment has been shown to reduce mortality ${ }^{18-21}$ and preserve left ventricular function ${ }^{22}$ in patients with ST elevation. For patients with ST depression the data are limited by a lack of statistical power and no benefit has been demonstrated..$^{182324}$ In many patients with ST depression the ischaemia producing coronary artery is patient, although usually containing thrombus, ${ }^{2}$ and it is therefore unlikely that thrombolytic treatment would improve perfusion in this group. These patients may therefore derive no benefit but be exposed to the bleeding risks of thrombolytic treatment. Our results may also in part be the result of the fact that thrombolytic treatment is procoagulant, as there is significant in vivo activation of platelets when streptokinase is used in acute myocardial infarction. ${ }^{25}$ Thrombolysis also exposes clot bound thrombin which is a potent stimulus for platelet aggregation. ${ }^{26}$ The thrombus may be, or may become, platelet rich $^{3}$ or extensively cross-linked with fibrin and resistant to thrombolysis. These procoagulant effects could result in conversion of a subocclusive to an occlusive thrombus and an increased incidence of infarction. ${ }^{1027}$

This study, like previous ones, ${ }^{18} 1923$ was not large enough to determine differences in mortality. The previous ISIS $-2,{ }^{18}$ third international study of infarct survival (ISIS-3), ${ }^{28}$ GISSI-1, ${ }^{19}$ and late assessment of thrombolytic efficacy (LATE) ${ }^{29}$ trials included a total of 3563 patients with ST depression. The mortality of the control patients was $13.8 \%$ and of the thrombolytic treated patients $15.2 \%{ }^{23}$; the confidence intervals in these trials were wide. In the present study the 1 year cardiac mortality was $6.3 \%$, considerably lower than in these trials and in the report by Lee $e t a{ }^{30}$ from Aberdeen of $26 \%$. In the retrospective observational study from Aberdeen the time from pain onset was not reported and the patients may have had more comorbidity. Furthermore, $54 \%$ had had a previous infarction compared with $34 \%$ in our study.

The thrombolysis in myocardial infarction (TIMI IIIB) study compared tissue plasminogen activator therapy with placebo in patients presenting within $24 \mathrm{~h}$ with unstable angina or non- $Q$ wave myocardial infarction and found no difference in outcome. ${ }^{24}$ This study was performed in the United States and Canada and reported a mortality of $2.4 \%$ at 6 weeks. ST depression was present in $32 \%$ and $41 \%$ had a history of prior myocardial infarction. A combined end point of mortality or myocardial infarction was $11.5 \%$ at 1 year. $^{31}$ The mean age of patients in the TIMI IIIB study (59 years) was younger than in those reported here (63 years) and almost a decade younger than those reported by Lee et $a^{30}$ ( 68 years). Age is an important determinant of outcome in patients with ST depression and it is likely that the differences in outcome at 1 year are in part a reflection of age differences. ${ }^{23}$ The better outcome in the TIMI IIIB trial may also relate to exclusion of patients with comorbidity.

Differences in outcome may also be the result of differences in revascularisation rates. Although the TIMI IIIB trial ${ }^{24}$ showed no differences in outcome at 6 weeks or 1 year for patients with unstable angina randomised to either a conservative strategy or invasive strategy, the revascularisation rates at 6 weeks were $49 \%$ in the conservative strategy group and $61 \%$ in the invasive strategy group. At 1 year the revascularisation rates were $58 \%$ in the conservative strategy group and $64 \%$ in the invasive strategy group. ${ }^{31}$ Had the rate of revascularisation in the conservative strategy group been significantly less, differences in outcome might have been shown. Revascularisation rates were not reported in the Aberdeen study. A strategy of selective expeditious revascularisation in patients with 
marked ST depression on the admission electrocardiogram or recurrent pain, especially if associated with recurrent ST depression, could result in a better outcome than a more conservative approach with revascularisation only for uncontrollable symptoms. In our study revascularisation was performed in $18 \%$ of patients within 35 days and $26 \%$ within 1 year.

Patients with ST depression and recent chest pain represent a heterogenous group at high and low risk in whom the coronary artery anatomy is not well defined..$^{32}$ Patients with thrombotic occlusion of a circumflex artery may well be a group in whom thrombolytic treatment may be beneficial. These patients cannot be readily identified, however, by standard 12 lead electrocardiographic criteria. ${ }^{33}$ Also severe ST depression of $\geqslant 3 \mathrm{~mm}$ is $90 \%$ specific for myocardial infarction on presentation, but which of these patients may benefit from thrombolytic treatment remains to be addressed.

Some patients who have single vessel disease present with a posterior or lateral myocardial infarction pattern on their electrocardiogram are at low risk. Patients at high risk include those with severe three vessel disease and those with a history of previous infarction and impaired left ventricular function. Assessment of left ventricular function and coronary angiography are important in identifying these patients as coronary artery bypass surgery may improve their long-term survival. ${ }^{34}$ In our study, patients with $\geqslant 2 \mathrm{~mm}$ ST depression were more likely to have a combined adverse outcome of death, late development of infarction, or need for urgent angiography. Whether some of these patients would benefit from an aggressive reperfusion protocol or revascularisation strategy, or both, remains to be determined.

Patients with ST depression and recent, prolonged chest pain frequently have infarction on admission. Administration of streptokinase does not reduce the incidence of infarction, death, need for angiography, or the number of positive exercise tests. The hospital and 1 year mortality are low in these selected patients when a strategy of medical treatment and selective expeditious revascularisation is used. Whether newer antithrombin agents such as hirudin ${ }^{35}$ or hirulog, ${ }^{36}$ or antiplatelet agents such as inhibitors of the IIb-IIIa receptors $^{37}$ or their combinations, will improve clinical outcome of patients presenting with ST depression remains to be shown by ongoing trials.

1 DeWood MA, Stifter WF, Simpson CS, et al. Coronary arteriographic findings soon after non-Q-wave myocardial infarction. $N$ Engl $\mathcal{F}$ Med 1986;315:417-23.

2 The TIMI IIIA investigators. Early effects of tissue-type plasminogen activator added to conventional therapy on the culprit coronary lesion in patients presenting with ischemic cardiac pain at rest: results of the thrombolysis in myocardial ischemia (TIMI IIIA) trial. Circulation 1993;87:38-52.

3 Mizuno K, Satumora K, Miyamoto A, et al. Angioscopic evaluation of coronary artery thrombi in acute coronary syndromes. N Engl f Med 1992;326:287-91.

4 Bär FW, Verheugt FW, Col J, et al. Thrombolysis in patients with unstable angina improves the angiographic but not the clinical outcome: results of UNASEM, a multicenter, randomized, placebo-controlled, clinical trial with anistreplase. Circulation 1992;86:131-7.

5 Telford AM, Wilson C. Trial of heparin versus atenolol in prevention of myocardial infarction in intermediate prevention of myocardial infarction in

6 Théroux P, Ouimet H, McCans J, et al. Aspirin, heparin, or both to treat acute unstable angina. $N$ Engl $\mathscr{f}$ Med 1988;319:1105-11.

7 Neri Serneri GG, Gensini GF, Poggesi L, et al. Effect of heparin, aspirin, or alteplase in reduction of myocardial ischaemia in refractory unstable angina. Lancet 1990; 335:615-8.

8 Théroux P, Waters D, Lam J, Juneau M, McCans J. Reactivation of unstable angina after the discontinuation of heparin. N Engl $\mathcal{F}$ Med 1992;327:141-5.

9 Topol EJ, George BS, Kereiakes DJ, et al. A randomized controlled trial of intravenous tissue plasminogen activator and early intravenous heparin in acute myocardial infarction. Circulation 1989;79:281-6.

10 Freeman MR, Langer A, Wilson RF, Morgan CD, Armstrong PW. Thrombolysis in unstable angina: randomized double-blind trial of t-PA and placebo. Circulation 1992;85:150-7.

11 Ambrose JA, Hjemdahl-Monsen CE, Borrico SW, Cohen $M$, Gorlin R, Fuster V. Quantitative and qualitative effects of intracoronary streptokinase in unstable angina and non-Q wave infarction. $\exists \mathrm{Am}$ Coll Cardiol 1987; and non- $Q$.

12 deZwaan C, Bar FW, Janssen JHA, deSwart HB, Vermeer F, Wellens HJ. Effects of thrombolytic therapy in unstable angina: clinical and angiographic results. $\mathcal{F} \mathrm{Am}$ Coll Cardiol 1988;12:301-9.

13 Nicklas JM, Topol EJ, Kander N, et al. Randomized, double-blind, placebo-controlled trial of tissue plasminogen activator in unstable angina. $\mathcal{F} \mathrm{Am}$ Coll Cardiol 1989; 13:434-41.

14 Gold HK, Johns JA, Leinbach RC, et al. A randomized, blinded, placebo-controlled trial of recombinant human tissue-type plasminogen activator in patients with unstable angina pectoris. Circulation 1987;75:1192-9.

15 Rentrop P, Blanke H, Karsch KR, Kaiser H, Köstering H, Leitz K. Selective intracoronary thrombolysis in acute myocardial infarction and unstable angina pectoris. Circulation 1981;63:307-17.

16 Williams DO, Topol EJ, Califf RM, et al. Intravenous recombinant tissue-type plasminogen activator in recombinant tissue-type plasminogen activator in placebo-controlled, randomized trial. Circulation 1990;82:376-83.

17 Lawrence JR, Shepherd JT, Bone I, Rogen AS, Fulton WFM. Fibrinolytic therapy in unstable angina pectoris: a controlled clinical trial. Thromb Res 1980;17:767-77.

18 ISIS-2 (Second International Study of Infarct Survival) collaborative group. Randomised trial of intravenous streptokinase, oral aspirin, both, or neither among 17187 cases of suspected acute myocardial infarction: ISIS-2. Lancet 1988;ii:349-60.

19 Gruppo Italiano per lo Studio della Streptochinasi nell'Infarto Miocardico (GISSI). Effectiveness of intravenous thrombolytic treatment in acute myocardial infarction. Lancet 1986;i:397-402.

20 Wilcox RG, von der Lippe G, Olsson CG, Jensen G, Skene AM, Hampton JR. Effects of alteplase in acute myocardial infarction: 6-month results from the ASSET study. Lancet 1990;335:1175-8.

21 AIMS Trial Study Group. Long-term effects of intravenous anistreplase in acute myocardial infarction: final venous anistreplase in acute myocardial infarction:

22 White HD, Norris RM, Brown MA, et al. Effect of intravenous streptokinase on left ventricular function and early survival after acute myocardial infarction. $N$ Engl $\mathcal{F}$ Med 1987;317:850-5.

23 Fibrinolytic Therapy Trialists' (FTT) Collaborative Group. Indications for fibrinolytic therapy in suspected acute myocardial infarction: collaborative overview of early mortality and major morbidity results from all randomised trials of more than 1000 patients. Lancet 1994;343:311-22.

24 The TIMI IIIB investigators. Effects of tissue plasminogen activator and a comparison of early invasive and conservative strategies in unstable angina and non-Q-wave myocardial infarction: results of the TIMI IIIB trial. Circulation 1994;89:1545-56.

25 Fitzgerald DJ, Catella F, Roy L, Fitzgerald GA. Marked platelet activation in vivo after intravenous streptokinase in patients with acute myocardial infarction. Circulation in patients with

26 Kroll MH, Schafer AI. Biochemical mechanisms of platelet activation. Blood 1989;74:1181-95.

27 Waters D, Lam JYT. Is thrombolytic therapy striking out in unstable angina? Circulation 1992;86:1642-4

28 ISIS-3 (Third International Study of Infarct Survival) Collaborative Group. ISIS-3: a randomised comparison of streptokinase vs tissue plasminogen activator vs anistreplase and of aspirin plus heparin vs aspirin alone among 41299 cases of suspected acute myocardial infarction. Lancet 1992;339:753-70.

29 LATE Study Group. Late assessment of thrombolytic efficacy (LATE) study with alteplase 6-24 hours after onset of acute myocardial infarction. Lancet 1993;342:759-66.

30 Lee HS, Cross SJ, Rawles JM, Jennings KP. Patients with suspected myocardial infarction who present with ST depression. Lancet 1993;342:1204-7. 
31 Anderson HV, Cannon C, Williams D, et al. One-year results of the TIMI-IIIB clinical trial [abstract] results of the 1994;90:I-231.

32 Roberts MJD, McNeill AJ, Dalzell GWN, et al. Doubleblind randomized trial of alteplase versus placebo in patients with chest pain at rest. Eur Heart $\mathcal{F} 1993 ; 14$ : 1536-42.

33 Kornreich F, Montague TJ, Rautaharju PM. Body surface potential mapping of ST segment changes in acute myocardial infarction: implications for ECG enrolmen criteria for thrombolytic therapy. Circulation 1993;87: 773-82.

34 Scott SM, Deupree RH, Sharma GVRK, Luchi RI, associates of the VA cooperative study of unstable angina. VA study of unstable angina: 10-year results show duration of surgical advantage for patients with impaired ejection of surgical advantage for patients with impaired ejection

hiol EJ, Fuster V, Harrington RA, et al. Recombinant hirudin for unstable angina pectoris: a multicenter, randomized angiographic trial. Circulation 1994;89: $1557-66$.

36 Fuchs J, McCabe CH, Antman EM, et al. Hirulog in the treatment of unstable angina: results of the TIMI 7 trial [abstract]. $₹$ Am Coll Cardiol 1994;II:56.

37 White HD, Charbonnier B, Van de Werf F, et al. An aspirin-controlled study of MK-852 in patients with unstable angina [abstract]. Circulation 1993;88: 1-201.

\section{IMAGES IN CARDIOLOGY}

\section{Guide wire graffito}

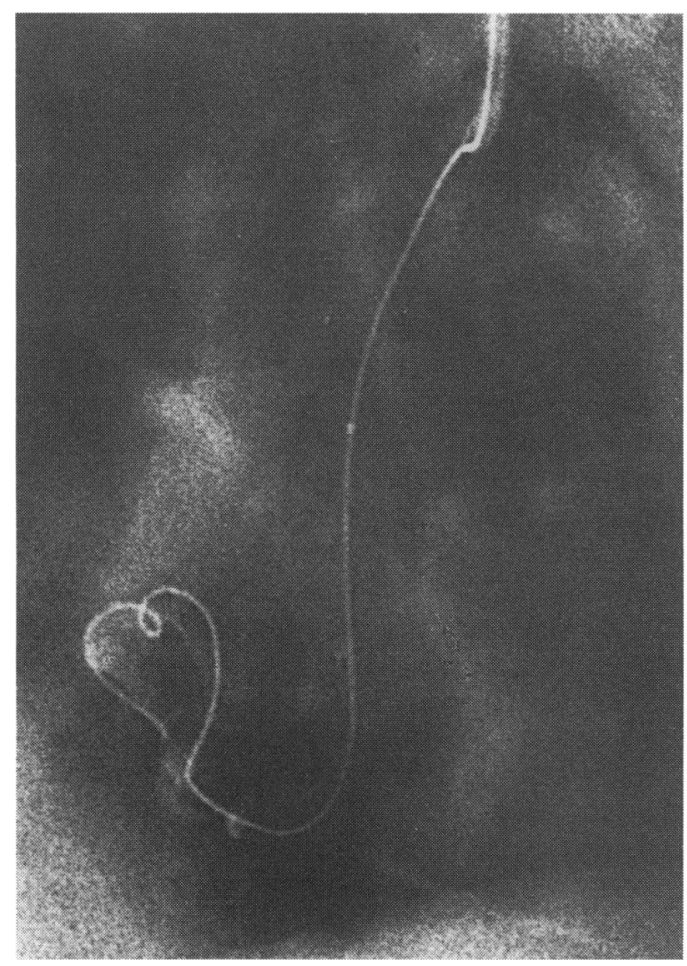

For cardiologists, coronary angioplasty has become a commonplace since its controversial beginnings in 1977. One operator (Professor Bernhard Meier of Bern) was reminded of the emotional dimensions of this high tech procedure when the guide wire graffito, shown opposite, appeared during a procedure. 